\title{
Validasi Metoda Analisis Penetapan Kadar Ketoprofen pada Tablet Salut Enterik secara Kromatografi Cair Kinerja Tinggi dan Spektrofotometri UV
}

(Validation of high-performance liquid chromatography and uv spectrophotometric methods for quantification of ketoprofen in enteric coated tablet)

\author{
Salman Umar $^{1 *}$, Saafrida² \& Henny Lucida ${ }^{1}$
}

${ }^{1}$ Fakultas Farmasi Universitas Andalas, Limau Manis, Kec. Pauh, Kota Padang, Sumatera Barat ${ }^{2}$ Balai Besar Pengawas Obat dan Makanan di Padang, Gn. Pangilun, Kec. Padang Utara, Kota Padang, Sumatera Barat

\begin{abstract}
Ketoprofen oral dosage forms marketed in Indonesia were mostly enteric-coated tablets. The purpose of this study was to develop and validation high-performance liquid chromatography (HPLC) and direct spectrophotometric method for the analysis of ketoprofen in enteric coated tablets. The assays and content uniformity test of tablets were carried out by an isocratic, reverse-phase HPLC validated method using $5 \mu \mathrm{m} \mathrm{RP-18}$ column $(250 \times 4.6 \mathrm{~mm}), \mathrm{pH} 6.5013 \mathrm{mM}$ phosphate buffermethanol $(40: 60 \mathrm{v} / \mathrm{v})$ as a mobile phase at a flow rate of $1.0 \mathrm{~mL} / \mathrm{min}$ and $\mathrm{UV}$ detection $258 \mathrm{~nm}$. The developed methods were validated for their linearity, accuracy, precision, limit of detection (LOD) and limit of quantitation (LOQ) in comparison with the UV spectrophotometric method. The HPLC method showed excellent linearity $(r>0.999)$ in the concentration range of $15-35 \mu \mathrm{g} / \mathrm{mL}$. Precision was demonstrated using \%RSD $<0.87$ and recoveries were good (\%R $>99.97$ ). The HPLC method was more sensitive than the UV spectrophotometric, due to the LOD/LOQ values of $0.18 / 1.20$ and $0.67 / 2.49 \mu \mathrm{g} / \mathrm{mL}$, respectively. The assays of ketoprofen enteric-coated tablets with the HPLC method were not significantly different from those with the UV spectrophotometric method $(P>0.05)$.
\end{abstract}

Keywords: ketoprofen; high performance liquid chromatography; validation method; enteric coated tablets.

ABSTRAK: Ketoprofen yang beredar di Indonesia sebagian besar dalam bentuk sediaan tablet salut enterik, tetapi metoda analisis untuk penetapan kadar dan uji disolusinya belum tersedia dalam farmakope. Tujuan dari penelitian ini adalah mengembangkan metode kromatografi cair kinerja tinggi (KCKT) dan spektrofotometri ultraviolet visibel (UV ) untuk melakukan analisis tablet salut enterik ketoprofen. Penetapan kadar dan keseragaman kandungan ketoprofen tablet salut enterik ditentukan secara KCKT isokratik fase terbalik yang telah divalidasi menggunakan kolom RP-18 $(250 \times 4,6 \mathrm{~mm})$ diameter partikel $5 \mu \mathrm{m}$, fase gerak metanol-dapar fosfat $13 \mathrm{mM} \mathrm{pH} \mathrm{6,5} \mathrm{perbandingan} \mathrm{60:40} \mathrm{v/v,} \mathrm{laju} \mathrm{alir} \mathrm{1,0} \mathrm{mL/menit} \mathrm{dan} \mathrm{detektor} \mathrm{UV} 258 \mathrm{~nm}$. Spesifisitas, linieritas, akurasi, dan presisi memenuhi persyaratan International Conference on Harmonization (ICH). Metode KCKT memberikan lineritas yang sangat baik $(r>0,999)$ pada rentang konsentrasi $15-35 \mu \mathrm{g} / \mathrm{mL}$, presisi dinyatakan dalam persen deviasi standar relative $(\%$ RSD $<0,87)$ dan perolehan kembali yang baik (R> 99,97\%). Metode KCKT lebih sensitif dibandingkan metode spektrofotometri UV, dengan nilai LOD masing-masing adalah 0,18 dan 0,67 $\mu \mathrm{g} / \mathrm{mL}$ serta $\mathrm{LOQ} 1,20$ dan 2,49 $\mathrm{\mu g} / \mathrm{mL}$. Hasil validasi dan uji penetapan kadar ketoprofen pada tablet salut enterik dengan metode KCKT tidak berbeda nyata dibandingkan dengan metode spektrofotometri UV $(P>0,05)$.

Kata kunci: ketoprofen; kromatografi cair kinerja tinggi; validasi metoda ; tablet salut enterik.

\section{Pendahuluan}

Ketoprofen (KP) adalah derivat asam propionat (Gambar 1), termasuk golongan obat anti inflamasi non steroid (OAINS) yang digunakan secara luas untuk mengatasi nyeri dan radang pada penyakit reumatik yang ringan serta gangguan otot skelet lainnya, digunakan juga untuk terapi nyeri setelah pembedahan ortopedik, gout akut dan dismenorea [1]. Di Indonesia, jumlah obat beredar dan terdaftar di Badan POM RI yang mengadung ketoprofen ada sekitar 98 data dalam berbagai bentuk sediaan, seperti; kapsul, tablet, larutan injeksi, suppositoria, gel, dan plester. Sebanyak 23 diantaranya adalah sediaan tablet salut enterik [2]. Sediaan tablet salut enterik ketoprofen dikembangkan untuk mengatasi efek samping yang merugikan apabila dikonsumsi secara oral [3]. Formula yang dikembangkan bertujuan mencegah obat lepas di lambung dan meningkatkan

*Corresponding Author: Salman Umar Fakultas Farmasi Universitas Andalas, Limau Manis, Kec. Pauh, Kota Padang, Sumatera Barat, 25175 | Email: umar salman@yahoo.com

\section{Article history}

Received: 30 Juni 2021 Accepted: 06 juli 2021 Published: 05 Agust 2021

Access this article

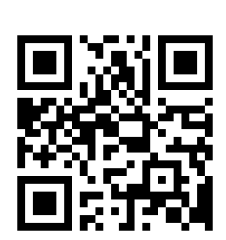


penyerapannya di saluran cerna $[4,5]$

Untuk memastikan kualitas produk obat yang dikonsumsi, terjamin keamanan dan stabilitasnya, diperlukan evaluasi sesuai prosedur kompendial atau metoda tervalidasi $[6,7]$. Sampai saat ini, belum ditemukan kompendial yang memuat monografi spesifik untuk sediaan tablet salut enterik ketoprofen $[6,8,9]$. Walaupun sudah tersedia monografi ketoprofen untuk sediaan yang berbeda, tetapi tetap diperlukan pengembangan dan validasi metoda analisis untuk memastikan metoda analisis sesuai dengan tujuan penggunaannya dan memastikan matriks tidak berpengaruh terhadap analisis zat aktif [6,10].

Penetapan kadar adalah salah satu parameter utama dalam monografi yang harus dilakukan untuk menjamin stabilitas suatu sediaan obat selama masa simpannya saat berada di pasaran dalam rangka pengawasan obat yang beredar ataupun sebagai syarat dalam regulasi pendaftaran sediaan obat oleh lembaga otoritas [7,11]. Beberapa metode analisis penetapan kadar ketoprofen dalam berbagai sediaan seperti tablet, kapsul, krim, gel topikal dan dalam sampel biologis, seperti darah, plasma dan urin telah dilaporkan, diantaranya menggunakan metode spektrofotometri [12,13], elektroforesis kapiler [14], dan kromatografi cair kinerja tinggi [15-17]. Metoda spektrofotometri adalah metoda analisis yang lebih poluler dan paling luas penggunaanya karena lebih mudah dalam penanganan, ekonomis, praktis, cepat dan tepat [18]. Sejalan dengan perkembangan teknologi instrumenisasi analisis, dewasa ini metoda KCKT banyak digunakan untuk pengujian kualitas mutu obat karena lebih efisien, spesifik, sensitif dan akurat $[19,20]$. Selain itu, pengujian dengan metoda KCKT banyak menjadi pilihan karena dapat memisahkan zat aktif dari gangguan matriks ataupun hasil degradasi $[15,16]$. Penelitian ini bertujuan untuk mengembangkan dan melakukan validasi metoda analisis penetapan kadar tablet salut enterik ketoprofen secara KCKT, mengadopsi metoda yang telah publikasikan, dengan pertimbangan penggunaan pelarut organik yang lebih sederhana dan efisien [17]. Selanjutnya hasil validasi dibandingkan dengan metoda spektrofotometri UV untuk dapat melihat sejauh mana kedua metoda tersebut memberikan perbedaan terhadap pengujian mutu kadar tablet salut enterik ketoprofen.

\section{Metode Penelitian}

\section{Bahan}

Pelarut: Metanol grade KCKT (Merck), Aquabidest (Ika Pharmindo), Aquadest (Brataco), reagen : Kalium dihidrogen fosfat $\left(\mathrm{KH}_{2} \mathrm{PO}_{4}\right)$ p.a (Merck), Sodium Hidroksida $(\mathrm{NaOH})$ p.a (Merck), Membran filter Regenerated Cellulose $0.45 \mu \mathrm{m}$ (Sartorius), Syringe filter polyvinylidene difluoride (PVDF) $0.45 \mu \mathrm{m}$ (Whatman ${ }^{\mathrm{TM}}$ ), Ketoprofen BPFI No Kontrol 205190 (kemurnian 100,3\%, susut pengeringan $0,01 \%$ ), tablet salut enterik ketoprofen merk dagang ( tablet $\mathrm{K}$ dan $\mathrm{P}$ ) dan generik berlogo (tablet $\mathrm{G})$ yang telah memenuhi persyaratan spesifikasi mutu label.

\section{KCK'T}

Pelarut: Metanol grade KCKT (Merck), Aquabidest (Ika Pharmindo), Aquadest (Brataco), reagen : Kalium dihidrogen fosfat $\left(\mathrm{KH}_{2} \mathrm{PO}_{4}\right)$ p.a (Merck), Sodium Hidroksida $(\mathrm{NaOH})$ p.a (Merck), Membran filter Regenerated Cellulose $0.45 \mu \mathrm{m}$ (Sartorius), Syringe filter polyvinylidene difluoride (PVDF) $0.45 \mu \mathrm{m}$ (Whatman ${ }^{\mathrm{TM}}$ ), Ketoprofen BPFI No Kontrol 205190 (kemurnian 100,3\%, susut pengeringan $0,01 \%$ ), tablet salut enterik ketoprofen merk dagang ( tablet $\mathrm{K}$ dan $\mathrm{P}$ ) dan generik berlogo (tablet $\mathrm{G})$ yang telah memenuhi persyaratan spesifikasi mutu label.

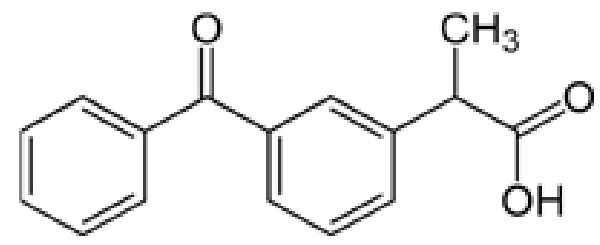

Gambar 1. Struktur kimia ketoprofen, 2-(3-benzoyl phenyl) propionic acid

Tabel 1. Data presisi metoda kromatografi cair kinerja tinggi (KCKT)

\begin{tabular}{lcc}
\hline \multicolumn{1}{c}{ Presisi } & Respon & \%RSD \\
\hline Sistem (UKS) & $970762 \pm 4727$ (area) & 0,49 \\
& $6,568 \pm 0,005(\mathrm{tR})$ & 0,08 \\
Metoda (PK) & $98,36 \pm 0,86$ & 0,87 \\
Intermediet (PK) & $98,57 \pm 1,15$ & 1,17 \\
\hline
\end{tabular}




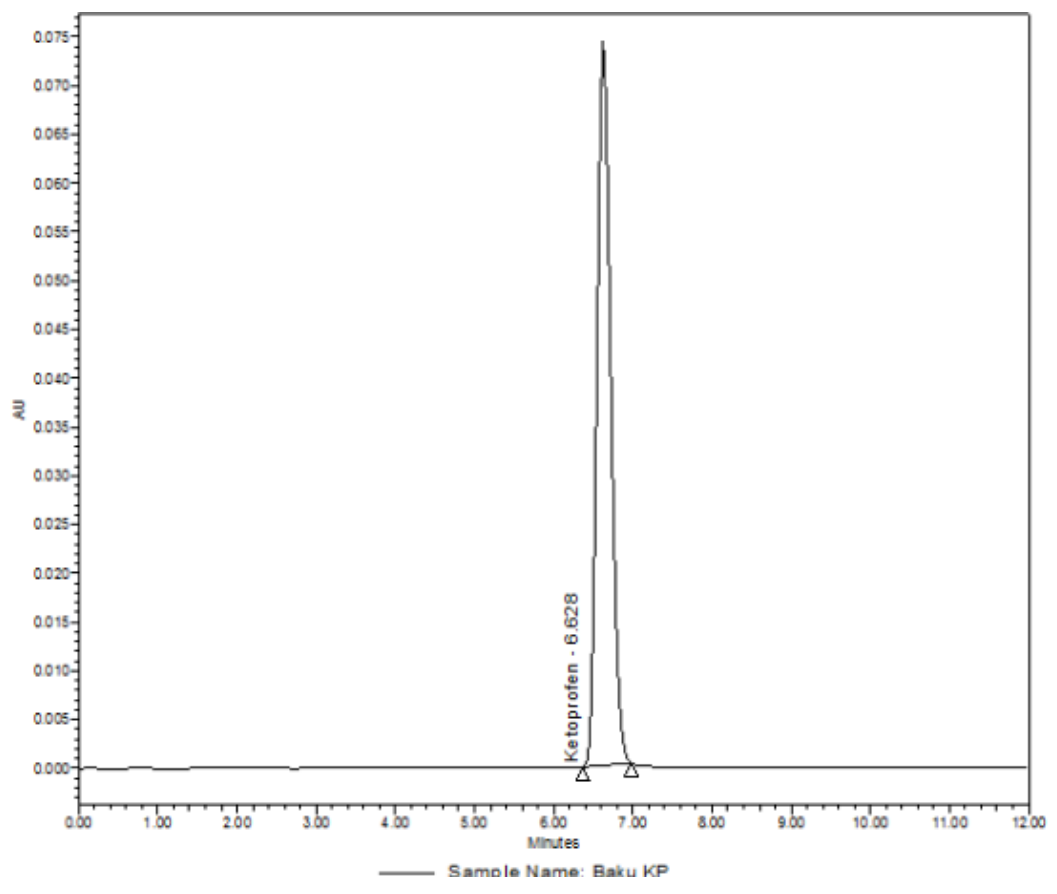

Gambar 2. Kromatogram larutan baku ketoprofen penetapan kadar menggunakan kolom RP18 $5 \mu \mathrm{m}$ (4.6 x 250) $\mathrm{mm}$, fase gerak campuran metanol dan dapar fosfat $13 \mathrm{mM} \mathrm{pH} \mathrm{6,5} \mathrm{dengan} \mathrm{perbandingan} \mathrm{(60} \mathrm{:}$ 40), laju alir $1,0 \mathrm{~mL} /$ menit dan detektor uv pada $\lambda 258 \mathrm{~nm}$

\section{Pembuatan Larutan Baku dan Larutan Uji Metoda} KCKT

Pelarut dibuat dengan mencampur homogen metanol dan larutan dapar fosfat $\left(13 \mathrm{mM} \mathrm{KH}_{2} \mathrm{PO}_{4}\right.$ diatur $\mathrm{pH} 6,5$ dengan $\mathrm{H}_{3} \mathrm{PO}_{4}$ ) dengan perbandingan 50:50 v/v. Larutan baku stok KP disiapkan dengan menimbang secara seksama 50 mg KP BPFI, dimasukkan ke dalam labu ukur 200,0 $\mathrm{mL}$, dan dilarutkan dengan pelarut hingga tanda batas, sehingga diperoleh larutan baku stok konsentrasi 0,25 mg/ $\mathrm{mL}$. Larutan baku stok dipipet 5,0 $\mathrm{mL}$ ke dalam labu ukur 50,0 mL, dicukupkan dengan pelarut hingga tanda batas untuk memperoleh larutan baku KP konsentrasi 0,025 $\mathrm{mg} / \mathrm{mL}$. Larutan baku disaring dengan membran filter PVDF 0,45 $\mu \mathrm{m}$ sebelum diinjeksikan.

Larutan uji: sebanyak 20 sampel tablet ditimbang dan dihitung bobot rata - ratanya, lalu diserbukkan hingga homogen. Serbuk ditimbang setara dengan $50 \mathrm{mg} \mathrm{KP} \mathrm{ke}$ dalam labu ukur 100,0 mL. Selanjutnya, ke dalam labu ditambahkan $75 \mathrm{~mL}$ pelarut dan disonikasi selama 15 menit, dicukupkan dengan pelarut hingga tanda batas, saring. 5,0 mL fitrat dimasukkan ke dalam labu ukur 100,0 $\mathrm{mL}$, cukupkan dengan pelarut hingga tanda batas. Larutan uji disaring dengan membran filter PVDF 0,45 $\mu \mathrm{m}$ sebelum diinjeksikan.

Keseragaman kandungan (KK) diuji dengan cara memasukkan tiap tablet ke dalam labu ukur 200,0 mL masing-masing sebanyak 10 labu. Selanjutnya diperlakukan sama dengan larutan uji PK.

\section{Uji Kesesuaiaan Sistem (UKS)}

Untuk menjamin sistem kromatografi memenuhi persyaratan untuk analisis sampel, dilakukan UKS dengan

Tabel 2. Hasil perhitungan penetapan kadar dan keseragaman kandungan tablet K, P dan G dengan metode kromatografi cair kinerja tinggi (KCKT)

\begin{tabular}{ccccc}
\hline \multirow{2}{*}{ Sampel } & \multicolumn{2}{c}{ Penetapan Kadar } & \multicolumn{2}{c}{ Keseragaman Kandungan } \\
\cline { 2 - 5 } & Rata-rata & \%RSD & Rata-rata & \%RSD \\
\hline Tablet K & $98,36 \pm 0,86$ & 0,87 & $98,81 \pm 0,69$ & 0,70 \\
Tablet P & $99,48 \pm 0,51$ & 0,51 & $98,27 \pm 0,97$ & 0,98 \\
Tablet G & $103,21 \pm 1,21$ & 1,18 & $103,86 \pm 1,33$ & 2,32 \\
\hline
\end{tabular}




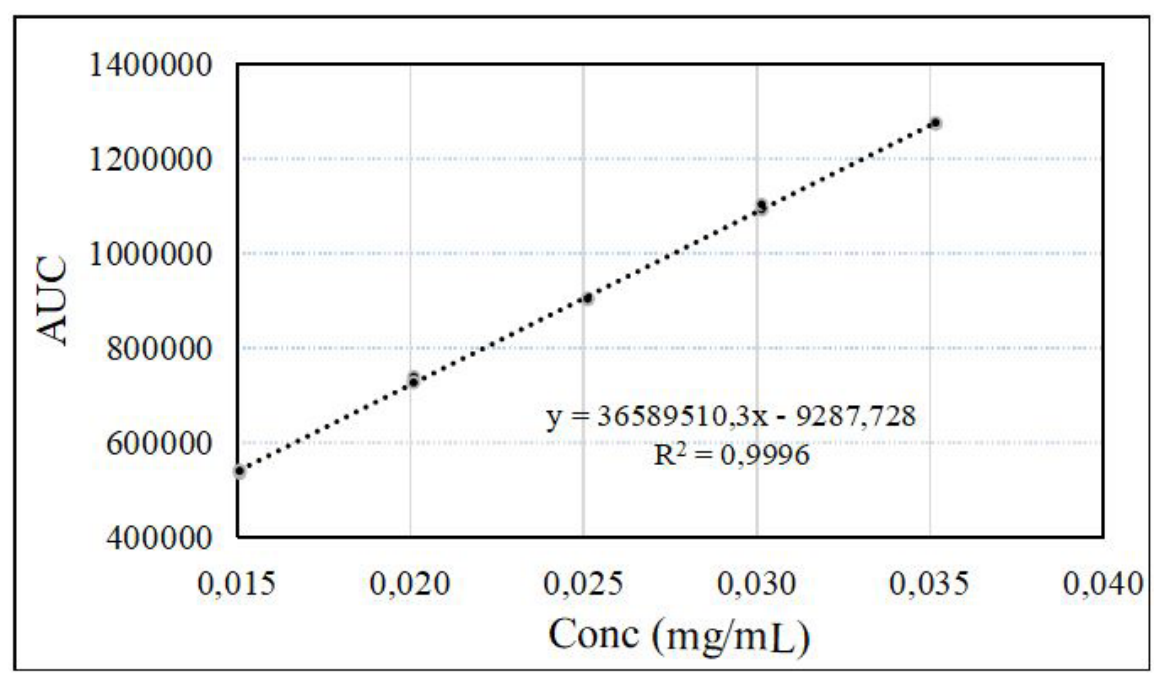

Gambar 3. Kurva linier larutan baku regresi ketoprofen dengan metode KCKT

cara menginjeksikan $10 \mu \mathrm{L}$ larutan baku KP 0,025 mg/mL enam kali berturut-turut sesuai kondisi yang dioptimasi. Persen deviasi standar relative (\%RSD) untuk waktu retensi (Rt) dan area harus memenuhi syarat $\leq 2,0 \%$, puncak ikutan $(\mathrm{T})<2,0$ dan jumlah plat teori $(\mathrm{N})>2000$ [20].

\section{Validasi Metoda}

Metoda KCKT yang telah dioptimasi divalidasi berpedoman pada International Conference on Harmonization (ICH) Q2 (R1) meliputi spesifisitas, linieritas, presisi, akurasi, LOD dan LOQ [21].
Penetapan Kadar dengan Metoda Spektrofotometri UV

Penetapan kadar (PK) KP secara spektrofotometri UV dilakukan dengan mengadopsi metoda PK yang tercantum pada monografi KP kapsul [8,9] menggunakan larutan metanol 75\%v/v dalam air sebagai pelarut. Larutan baku stok dipersiapkan dengan cara melarutkan KP BPFI yang ditimbang seksama 12,5 mg dan dimasukkan ke dalam labu 100,0 mL. Ditambahkan $70 \mathrm{~mL}$ pelarut, disonikasi selama 15 menit dan dicukupkan dengan pelarut sampai tanda batas. Larutan baku stok $(0,125 \mathrm{mg} / \mathrm{mL})$ dipipet sejumlah 2,0 $\mathrm{mL}$ ke dalam labu ukur 50,0 mL, ditambahkan pelarut sampai tanda batas, dikocok homogen. Serapan diukur
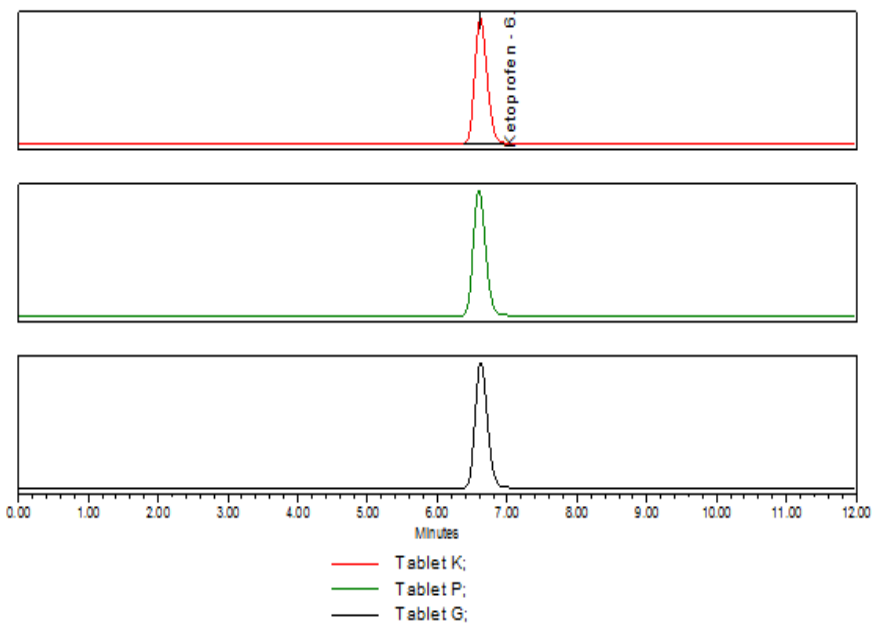

Gambar 4. Profil kromatogram penetapan kadar tablet K, P dan G menggunakan kolom RP18 $5 \mu \mathrm{m}$ (4.6 x 250) $\mathrm{mm}$, fase gerak campuran metanol dan dapar fosfat $13 \mathrm{mM} \mathrm{pH} \mathrm{6,5} \mathrm{dengan} \mathrm{perbandingan} \mathrm{(60} \mathrm{:}$ 40), laju alir $1.0 \mathrm{~mL} /$ menit, suhu $30^{\circ} \mathrm{C}$ dan detektor UV pada $\lambda 258 \mathrm{~nm}$ 

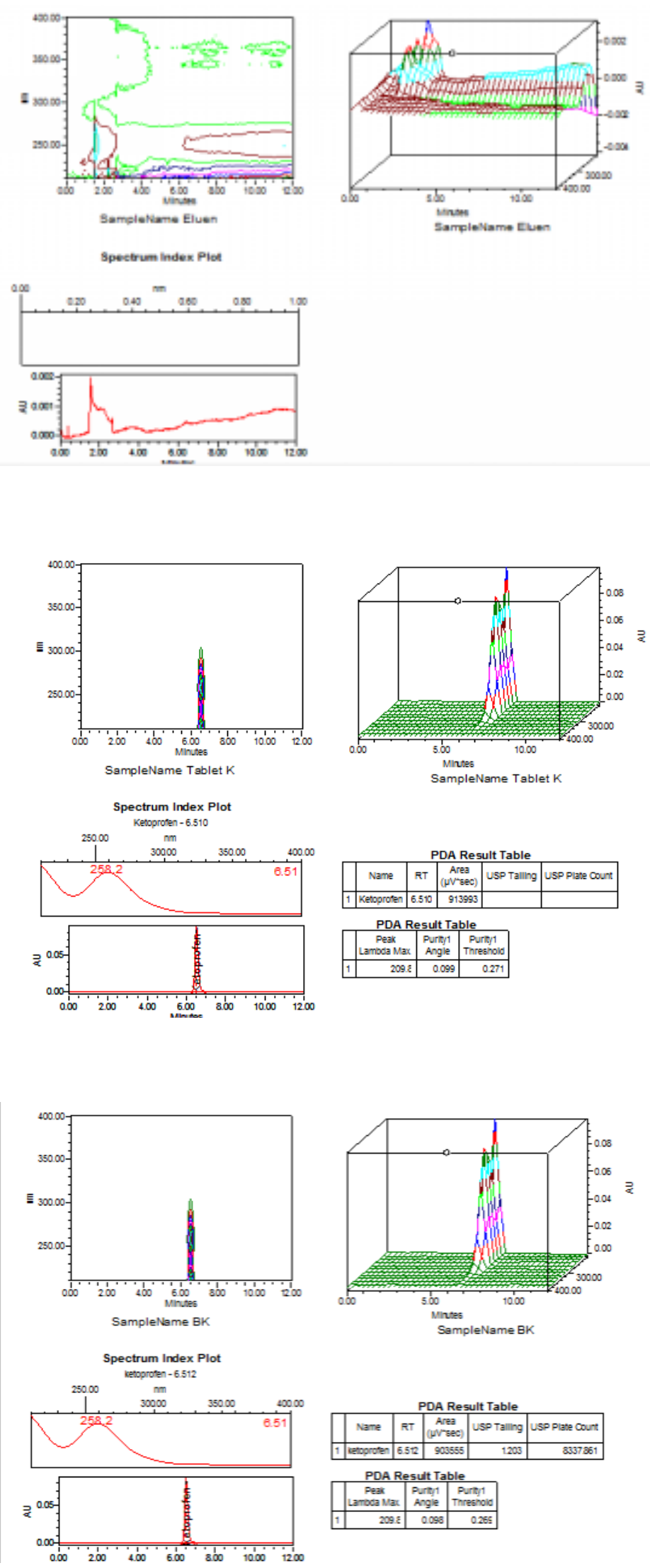

Gambar 5. Overlay kontur, 3D kromatogram photo dioda array (PDA) dan spektrum indeks masingmasing (dari atas ke bawah) dari eluen, tablet $\mathrm{K}$ dan baku ketoprofen 
pada panjang gelombang $\lambda 258 \mathrm{~nm}$ dengan larutan metanol $75 \%$ sebagai blanko.

Pembuatan larutan uji : Sebanyak 20 sampel tablet ditimbang dan dihitung bobot rata - rata per tablet, lalu diserbukkan hingga homogen. Serbuk ditimbang setara dengan $20 \mathrm{mg}$ KP dan dimasukkan ke dalam labu ukur 100,0 mL, ditambahkan $70 \mathrm{~mL}$ pelarut, disonikasi selama 15 menit dan dicukupkan dengan pelarut hingga tanda batas, kocok homogen. Saring larutan dengan kertas saring. Filtrat sebanyak 3,0 mL dipipet ke dalam labu ukur 100,0 $\mathrm{mL}$, dicukupkan dengan pelarut sampai tanda batas, lalu dikocok hingga homogen. Serapan diukur pada panjang gelombang $\lambda 258 \mathrm{~nm}$.

\section{Hasil dan Diskusi}

Profil kromatogram yang didapatkan setelah proses optimasi metoda dapat dilihat pada Gambar 2 memberikan puncak yang simetris dan waktu uji yang singkat. UKS memenuhi syarat keberterimaan [20], yaitu \%RSD 0,08\% (Rt) $0,49 \%$ (area), tailing 1,18 dan $\mathrm{N}$ plate $6676,5 \pm 16,6$. Presisi atau derajat keberulangan dinyatakan dengan presisi untuk sistem (UKS), metoda dan intermediet (Tabel 1). Presisi metoda adalah rata-rata kadar dari 10 kali ulangan penetapan kadar sampel tablet $\mathrm{K}$, dan presisi intermediet merupakan perlakuan yang sama tetapi pada hari yang berbeda. Semua parameter memenuhi syarat $\%$ RSD $<2,0 \%$ [21]. Kurva regresi dipersiapkan dengan membuat lima level konsentrasi larutan baku KP. Masing-masing dilakukan pengulangan tiga kali. Respon yang didapatkan diplot antara konsentrasi dan AUC. Gambar 3 memperlihatkan hubungan yang linier antara konsentrasi dan AUC pada rentang konsentrasi $15 \mu \mathrm{g} /$ $\mathrm{mL}$ sampai $35 \mu \mathrm{g} / \mathrm{mL}$. Penetapan kadar dan keseragaman kandungan dari tiga tablet yang diuji dengan metoda KCKT memenuhi syarat kompendial 90,0-110,0\% dan $\%$ AV $\leq 15 \%$ (Tabel 2) [6,7]. Kromatogram penetapan kadar semua sampel tablet yang diuji dapat dilihat pada Gambar 4, memperlihatkan semua kromatogram memberikan performa yang sama dengan baku KP. Overlay kontur atau tampak atas kromatogram, kromatogram tiga dimensi (3D) dan spektrum hasil ekstraksi kromatogram pada channel $\lambda 258$ dapat dilihat pada Gambar 5. Pelarut tidak memberikan serapan spesifik pada area lambda 200-400 $\mathrm{nm}$, Larutan baku KP dan sampel tablet $\mathrm{K}$ memberikan profil spektrum UV yang identik dan $\lambda$ maksimum pada $258 \mathrm{~nm}$. Penampakan 3D juga memperlihatkan tidak ada interfensi atau puncak lain pada puncak larutan baku dan sampel. Kemurnian kromatogram dapat diketahui dengan membandingan nilai purity angle dengan purity

Tabel 3. Data parameter validasi metoda penetapan kadar tablet salut enterik K menggunakan metoda kromatografi cair kinerja tinggi (KCKT) dan spektrofotometri UV

\begin{tabular}{lcc}
\hline \multicolumn{1}{c}{ Parameter } & KCKT & Spektrofotometri UV \\
\hline Persamaan Linieritas & & \\
Slope & 36589510,3 & 0,06753 \\
Intersep & $-9287,73$ & $-0,0078$ \\
koofisien korelasi r2 & 0,9996 & 0,9998 \\
Presisi ( $\mathbf{n}=10)$ & 1,167 & 1,781 \\
Akurasi (n=3) & & \\
80\% & $98,24 \pm 1,28$ & $101,79 \pm 0,73$ \\
100\% & $98,07 \pm 0,84$ & $101,24 \pm 1,62$ \\
120\% & $99,97 \pm 1,48$ & $98,94 \pm 0,23$ \\
LOD & $0,18 \mathrm{ppm}$ & $0,67 \mathrm{ppm}$ \\
LOQ & $1,20 \mathrm{ppm}$ & $2,49 \mathrm{ppm}$ \\
Kadar (n=20) & & 46,54 \\
Tablet K & 98,34 & $97,71 \%$ \\
Tablet P & 99,47 & $99,73 \%$ \\
Tablet G & 103,20 & $101,08 \%$ \\
\hline
\end{tabular}


Tabel 4. Hasil uji t-student parameter validasi metoda kromatografi cair kinerja tinggi (KCKT) dan spektrofotometri UV

\begin{tabular}{cccc}
\hline Parameter & t hitung & T tabel $(\mathbf{\alpha} \mathbf{0 , 0 5} \mathbf{n}-\mathbf{1})$ & Hasil \\
\hline Akurasi $(n=9)$ & $-2,059$ & 2,306 & Terima H0 \\
Presisi $(n=10)$ & 1,420 & 2,262 & (tidak berbeda nyata) \\
Penetapan Kadar $(n=3)$ & 1,200 & 4,303 & pada P $>0,05$ \\
\hline
\end{tabular}

treshold, dimana hasil perbandingannya harus kecil dari 1 [17]. Rasio purity angle dan purity treshold larutan baku KP dan sampel tablet $\mathrm{K}$ yang didapatkan dari hasil pengolahan software Empower ${ }^{\mathrm{TM}} 3$ masing-masing adalah 0,364 dan 0,604. Uji spesifisitas menggunakan metoda spektrofotometri UV menggunakan larutan metanol 75\% $\mathrm{v} / \mathrm{v}$ sebagai blanko memperlihatkan spektrum baku dan sampel yang identik pada $\lambda$ maksimum $258 \mathrm{~nm}$. Pelarut dan matriks tidak memberikan interfensi pada area serapan ketoprofen. Menunjukkan bahwa kedua metoda yang digunakan untuk penetapan kadar ketoprofen dalam tablet salut enterik dapat digunakan untuk menguji mutu kadar. Apabila ada gangguan dari matriks atau degradasi zat aktif, atau untuk pengujian kemurnian ketoprofen, maka metoda KCKT lebih disarankan. Sebagaimana telah dilaporkan pada penelitian sebelumnya, ketoprofen mengalami degradasi karena oksidasi dan fotolisis, memberi serapan pada $\lambda 258 \mathrm{~nm}$, tetapi terpisah dari puncak ketoprofen. Puncak degradasi terdeteksi pada Rt 16 menit [17].

Parameter validasi metode KCKT dan spektrofotometri UV mencakup uji linieritas, presisi, akurasi, LOD dan LOQ masing-masing dievaluasi dan dibandingkan. Kedua metode memberikan linieritas yang baik ( $r>0,999)$, perulangan sepuluh kali hasil penetapan kadar sampel memenuhi syarat presisi $\%$ RSD $<2,0 \%$ dan akurasi pada level konsentrasi 80\%, 100\% dan 120\% dari konsentrasi untuk penetapan kadar memenuhi syarat keberterimaan, yaitu rentang 98-102\% [18]. Perolehan kembali (recovery) menggunakan metoda spektrofotometri UV lebih besar, pada level $80 \%$ dan 100\%. Bisa jadi karena komposisi pelarut organik yang digunakan untuk mengekstraksi sampel lebih besar jika dibandingkan dengan metoda KCKT, sehingga ketoprofen yang terlarut lebih besar. Metode KCKT lebih sensitif dengan perolehan LOD dan LOQ yang lebih kecil dibandingkan dengan metode spektrofotometri UV. Data dapat dilihat pada Tabel 2. Hasil uji statistik (Tabel 3) menggunakan t-student terhadap parameter validasi metode KCKT dibandingkan terhadap metode spektrofotometri UV tidak berbeda nyata pada $\mathrm{P}>0,05$.
Metoda analisis dengan metoda KCKT yang divalidasi menggunakan tablet salut enterik ketoprofen (tablet K) memberikan nilai presisi dan akurasi yang tidak berbeda jauh dengan hasil validasi yang telah dilaporkan sebelumnya [17]. Hasil yang berbeda didapatkan pada nilai LOD dan LOQ yang lebih besar jika dibandingkan pada penelitian sebelumnya (LOD $0,025 \mu \mathrm{g} / \mathrm{mL}$ dan LOQ $0,05 \mu \mathrm{g} / \mathrm{mL}$ ). Perbedaan tersebut karena pada penelitian sebelumnya kurva linieritasnya dibuat pada range konsentrasi $0,05-250 \mu \mathrm{g} / \mathrm{mL}$ sehingga memberikan hasil yang lebih sensitif. Berdasarkan hasil validasi, baik metoda KCKT dan spektrofotometri UV dapat dipertimbangkan untuk diterapkan sebagai metoda analisis pengembangan uji disolusi dalam rangka melengkapi parameter pengujian mutu tablet salut enterik ketoprofen

\section{Kesimpulan}

Hasil validasi analisis penetapan kadar ketoprofen dengan metode KCKT dan spektrofotometri UV akurat, simpel, sederhana, dan spesifik untuk digunakan dalam analisis rutin pengujian tablet salut enterik ketoprofen. Masing-masing metoda dapat disesuaikan dengan kondisi laboratorium dan tujuan pengujian.

\section{Ucapan Terima Kasih}

Terimakasih kepada Badan Pengawas Obat dan Makanan Republik Indonesia yang telah yang telah mendanai penelitian ini melalui program tubel No. KP.07.03.2.82.07.19.2237 tahun 2019.

\section{Referensi}

[1]. E.Shohin I, Kulinich JI, Ramenskaya G V., Abrahamsson B, Kopp S. Biowaiver Monographs for Immediate-Release Solid Oral Dosage Forms: Ketoprofen. J Pharm Sci. 2012;101(7):2271-80. https://doi. org/10.1002/ips

[2]. BPOM RI: Cek Produk BPOM, [Online] [Accessed 22 juni 2020]. https://cekbpom.pom.go.id/home/produk 
[3]. Matsui H., Shimokawa o., Kaneko T., Nagano Y., Rai K., Hyodo I. The pathophysiology of non-steroidal anti-inflammatory drug (NSAID)induced mucosal injuries in stomach and small intestine. J Clin Biochem Nutr. 2011;48(2):7-111. https://doi.org/10.3164/jcbn. $\underline{10-79}$

[4]. Kulkarni R, Sa B. Enteric delivery of ketoprofen through functionally modified poly(acrylamide-grafted-xanthan)-based $\mathrm{pH}$-sensitive hydrogel beads: Preparation, in vitro and in vivo evaluation., J Drug Target., 2008;16(2):167-77. $\quad$ https://doi.org/10.1080/1061186070179 2399M

[5]. Arida Al, Al-Tabakha MM. Encapsulation of ketoprofen for controlled drug release. European Journal of Pharmaceutics and Biopharmaceutics, 2007;66(1):48-54. https://doi.org/10.1016/i. ejpb. 2006.09.010

[6]. USP, The United States Pharmacopeia: the National Formulary (USP39-NF34). Easton: Mack Publishing Co; 2016.

[7]. FDA, SUPAC-MR : Modified Release Solid Oral Dosage Forms. ScaleUp and Post Approval Changes: Chemistry, Manufacturing, and Controls; In Vitro Dissolution Testing and In Vivo Bioequivalence Documentation. Washington,DC, U.S. Government Printing Office; 1997.

[8]. Menkes RI, Farmakope Indonesia (ed.V), Jakarta: Departemen Kesehatan RI; 2014.

[9]. BP, British Pharmacopoeia (B.P.). London, UK: The Stationery Office on behalf of the Medicines and Healthcare products Regulatory Agency (MHRA); 2017.

[10]. De Melo J, Hurtado FK, Prado AW, Souza MJE, Rolim CMB. Validation of HPLC and UV spectrophotometric methods for the determination of bezafibrate in pharmaceutical formulations. J Liq Chromatogr Relat Technol. 2008;31(2):269-80. https://doi. org/10.1080/10826070701739108

[11]. Bajaj, S., Singla, D., \&, Sakhuja, N. Stability testing of pharmaceutical products. Journal of applied pharmaceutical science, 2012;2(3),129138. https://doi.org/10.7324/JAPS.2012.2322

[12]. El-Saharty, Y. S., Metwally, F. H., Refaat, M., \& El-Khateeb, S. Z. Simultaneous Determination of Hyoscine Butylbromide and Ketoprofen in Pharmaceutical Preparations by Spectrophotometric and Liquid Chromatographic Methods, Journal of AOAC International, 2007;90(1):102-112., https://doi.org/10.1093/jaoac/90.1.102

[13]. Özlü C, Basan H, Şatana E, Ertaş N, Göğer NG., Quantitative determination of ketoprofen in gels and ampules by using flow-injection UV spectrophotometry and HPLC: Journal of Pharmaceutical and Biomedical Analysis; 2005,39 (3-4): 606-11. https://doi.org/10.1016/j.jpba.2005.04.002
[14]. Blanco, M., González, J., Torras, E., \& Valverde, I. Enantiomeric purity determination of ketoprofen by capillary electrophoresis: development and validation of the method. Analytical and bioanalytical chemistry. 2003,375(1):157-163. https://doi. org/10.1007/s00216-002-1629-8

[15]. Dvořák, J., Hajkova, R., Matysova, L., Novakova, L., Koupparis, M. A., \& Solich, P.,Simultaneous HPLC determination of ketoprofen and its degradation products in the presence of preservatives in pharmaceuticals.: Journal of pharmaceutical and biomedical analysis. 2004;36(3),625-629., https://doi.org/10.1016/i. jpba.2004.07.018.

[16]. Bempong, D. K. \& Bhattacharyya, L., Development and validation of a stability-indicating high-performa liquid chromatographic assay for ketoprofen topical penetrating gel.: Journal of Chromatography A. 2005;1073(1-2),341-346. https://doi.org/10.1016/j. chroma.2004.12.061

[17]. Yadav, N. K., Raghuvanshi, A., Sharma, G., Beg, S., Katare, O. P., \& Nanda, S, QbD-based development and validation of a stabilityindicating HPLC method for estimating ketoprofen in bulk drug and proniosomal vesicular system.: Journal of Chromatographic Science. 2016;54(3),377-389., https://doi.org/10.1093/chromsci/bmv151

[18]. Parmar, A. \& Sharma, S., Derivative UV-vis absorption spectra as an invigorated spectrophotometric method for spectral resolution and quantitative analysis: Theoretical aspects and analytical applications: A review.. TrAC Trends in Analytical Chemistry. 2016;77, 44-53. https://doi.org/10.1016/j.trac.2015.12.004

[19]. Mendez, A.S.S.M. \&. S.E., Validation of HPLC and UV spectrophotometric methods for the determination of meropenem in pharmaceutical dosage form. Journal of pharmaceutical and biomedical analysis. 2003;33(5),947-954. https://doi.org/10.1016/ s0731-7085(03)00366-2

[20]. Ahuja, S., \& Rasmussen, H, eds. HPLC method development for pharmaceuticals.. Amterdam, Netherlands: Elsevier, 2011.

[21]. Dagron S. Die International Conference on Harmonization of Technical Requirements for Registration of Pharmaceuticals for Human Use (ICH). Handb Ethik und R der Forsch am Menschen. 2014;541-5. https://doi.org/10.1007/9783642-35099-3 86. 